\title{
MAPPING PLANT WATER CONTENT OF WHEAT CROPS BY SATELLITE IMAGERY
}

\author{
Adel H. Elmetwalli*
}

\begin{abstract}
Mapping plant water content (PWC) by means of earth observation provides the opportunity for understanding and characterising plant water status of crops at a regional scale and enable more efficient irrigation management. The overall aim of this investigation was to assess the potential of ASTER high resolution satellite imagery to map regional PWC variations in irrigated wheat in the Nile Delta of Egypt. Vegetation indices; NDVI, RVI, GNDVI $I_{b r}$ and NDWI, were derived from ASTER imagery to relate them to $P W C$. The results demonstrated that PWC variation of wheat crops can be detected using ASTER high resolution satellite images through the derived vegetation indices. The SWIR radiation of the electromagnetic spectrum centred at $1656 \mathrm{~nm}$ showed high sensitivity to PWC and thus NDWI based on this region demonstrated the best relationships with $P W C\left(R^{2}=0.74\right)$. The results therefore demonstrated the feasibility of using high resolution satellite images, including ESA's forthcoming GMES Sentinel 2, to give a better understanding of crop water status at a regional scale.
\end{abstract}

Keywords: wheat, remote, sensing, water, status, mapping

\section{INTRODUCTION}

W heat (Triticum aestivum L.) is ranked the first cereal crop worldwide for food consumption and is equally important for the Egyptian Economy since the Egyptian Government imports about half the 18.8 million tonnes of wheat needed for population consumes a year at a cost of $\$ 1.6$ billion (Egyptian Ministry of Agriculture, 2012). Maximizing crop production via the optimization of irrigation could reduce the budget necessary for the importing wheat and will provide greater national food security (Ren et al., 2008). The growing area for wheat crops in the Nile Delta accounts for more than $40 \%$ of the total cultivated area in the winter season.

\footnotetext{
*Assi. Prof., Agric. Eng. Dept., Fac. of Agric., Tanta Univ., Egypt.
} 
In this context, monitoring crop health for winter wheat production will provide a strategically valuable tool for optimizing production. There is considerable variability in water availability throughout the cultivated area in the Nile Delta and wheat productivity is affected by many environmental factors. Water stress is considered the main factor affecting wheat productivity (Sun et al., 2006) and thus monitoring crop water status is crucial. The conventional method of identifying plant water content (PWC) is to dry plant materials in an oven for a specific period of time until reaching a constant weight and find the difference between wet and dry weight divided by the wet weight whilst this method is very simple, reliable and easy to perform, it is time consuming and needs more labour particularly if it is needed at large scales. Conversely, data acquired through earth observation can provide a robust, quick and accurate tool in PWC estimations.

Among different ways of monitoring wheat crop productivity, remote sensing technology offers a suitable alternative for crop conditions and yield forecasting since it gives a timely, accurate and objective estimation of various yield-directly related parameters (Ren et al., 2008). Reflected radiation in the near infrared (NIR) region of the electromagnetic spectrum has been reported by previous studies as a sensitive region for assessing PWC (Penuelas et al., 1997; Ceccato et al., 2001). Penuelas et al. (1996) concluded that reflectance in the NIR region at $950-970 \mathrm{~nm}$ corresponding to a weaker water absorption band is a reliable region for measuring plant water concentration.

Mapping PWC can help managing irrigation scheduling of agricultural crops and monitor areas suffering from drought stress (Ben-Gal et al., 2009). Other studies showed that the shortwave infrared region (SWIR) is greatly affected by the concentration of plant water content particularly the region from 1530 to $1720 \mathrm{~nm}$ (Fourty and Baret, 1997). Some studies used Normalized Difference Vegetation Index (NDVI) and Normalized Difference water Index (NDWI) for estimating PWC (Gao, 1996 and Jackson, 2004). Ceccato et al. (2001 and 2002) developed an index derived from SPOT imagery to detect PWC and found that the SWIR region was critical for estimating PWC. Indices contrasting the 
SWIR radiation with NIR radiation are sensitive to the mass or the volume of water in plant materials (Cheng et al., 2008). Tucker (2005) documented the usefulness of the traditional NDVI derived from satellite imagery such as AVHRR and MODIS in quantifying PWC. However some other studies demonstrated the low capability of the visible near infrared VNIR based indices in detecting the concentration of plant water content (Chen et al., 2005; Jackson et al., 2004). Cheng et al. (2013) investigated the possibility of MODIS/ASTER (MASTER) data to detect diurnal variations in orchard canopy water content and reported the possibility of detecting canopy water content using simple spectral indices derived from MASTER data. They also concluded that Normalized Difference Infrared Index (NDII) was more sensitive to crop water content more than NDVI with respective $R^{2}$ values of 0.42 and 0.39 .

The overall aim of this research was to assess the potential of high resolution satellite imagery to map PWC at a regional scale for an area characterized by relatively small field systems and to establish the efficiency of remote sensing imagery in monitoring crop water status as a useful tool in irrigation scheduling.

\section{MATERIALS AND METHODS}

\section{Study Site and Sampling Strategy}

Unknown variations in crop health status with a mix of traditional and modern irrigation methods and variations in soil types within the Nile Delta needs accurate technologies to be monitored. This presents a useful study site to test the effectiveness of satellite imagery in quantifying water status of wheat. The study area is located south-west of the Nile Delta of Egypt with a latitude of $30^{\circ} 55^{\prime} 33^{\prime \prime}$ and longitude of $29^{\circ} 56^{\prime} 23^{\prime \prime}$ (Fig. 1) and comprises roughly $200 \mathrm{~km}^{2}$ of different irrigated agricultural crops. The study site is a flat irrigated area cultivated mainly with wheat and clover in the winter season. The soil of the study site is described as a sandy loam to sandy in some areas nearby the desert. Traditional flood irrigation is the most commonly used method throughout the study area. Some farmers in the newly reclaimed areas use sprinkler and drip irrigation systems for growing fruit trees. 
Fieldwork visits covered most of the study area to have a range of stress levels in fields.

The predominant weather in the investigated area is characterised by hot summers and mild winters with respective temperatures of $30.2^{\circ} \mathrm{C}$ and $18.4{ }^{\circ} \mathrm{C}$; average precipitation 0 and $35 \mathrm{~mm}$ per annum; average wind speed $10-15 \mathrm{~km} / \mathrm{hr}$; relative humidity 55 and $70 \%$. The wheat-growing season in this area starts in mid-November and ends beginning of May. The weather conditions in March and April are generally cloudless, which benefit the acquisition of excellent satellite images (cloud cover typically $<5 \%$ ).

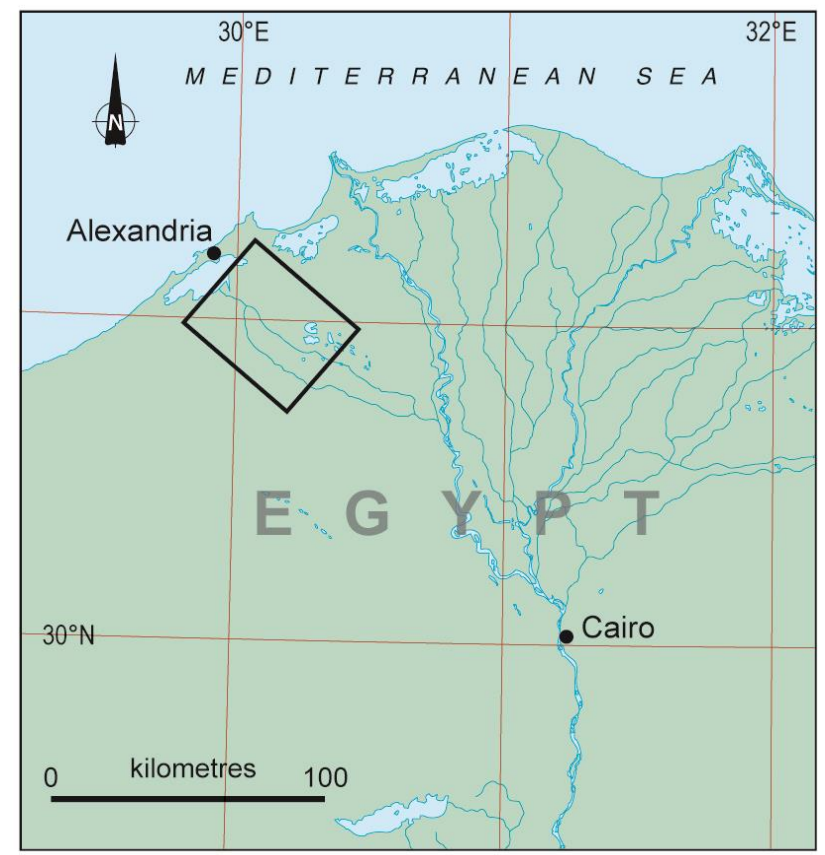

Fig.1 A map showing the study site south Alexandria, Egypt

\section{Image Acquisition and Processing}

ASTER satellite imagery was used for this study. The satellite passed the study site on March 24, 2010 under clear sky conditions and acquired an image at 10.16 GMT. ASTER captures high spatial resolution data in 14 bands, from the visible to the thermal infrared wavelengths. Following the geo-correction using image to image technique, the image was also atmospherically corrected using FLAASH module available with the 
ENVI $^{\mathrm{TM}}$ v4.7 software package. The atmospheric correction was based on a mid-latitude summer and rural aerosol models. The SWIR region of the image was then resampled to $15 \mathrm{~m}$ resolution. The corrected image was classified using Minimum Distance (MD) supervised classification to identify different crops and other classes in the study area.

The spectral signatures from sampled fields were derived using the region of interest technique (ROIs). From the fieldwork campaign conducted in March and April 2010, some fields with a range of stress levels were chosen to collect vegetation samples weekly to use as ground reference data. A field survey was undertaken prior field work visits to visually identify stressed and healthy areas. A minimum of 20 pixels was used for extracting the spectral signature at each location. Small-field system in some areas in the region makes it difficult sometimes to have a sufficient number of pixels, so care was taken to choose big fields. The spectral signature of each sampled location was derived from at least 9 pixels to reduce the variability within field. The mean spectra were used for calculating different vegetation indices. The sampled locations were always chosen away from the field borders. Statistics of the spectral signature done in ENVI were copied to a separate file to calculate different vegetation indices. The used vegetation indices included;

$\mathrm{NDVI}=\frac{N I R-\operatorname{Re} d}{N I R+\operatorname{Re} d} \quad \mathrm{RVI}=\frac{N I R}{\operatorname{Re} d}$

$\mathrm{GNDVI}_{\mathrm{br}}=\frac{N I R-\text { green }}{N I R+\text { green }} \quad \mathrm{NDWI}=\frac{N I R-S W I R}{N I R+S W I R}$

Where:

NDVI is normalized difference vegetation index

RVI is Ratio Vegetation Index

GNDVI $_{\text {br }}$ is Green Normalized Difference Vegetation Index, and NDWI is Normalized Difference Water Index

In this study, different portions of the SWIR region were tested to choose the most sensitive wavelength to PWC. Wavelengths centred at 1656, 2167, 2209, 2262, 2336, and $2400 \mathrm{~nm}$ were tested. 


\section{Collecting Plant Material}

The field data collection was planned to couple with the acquisition of satellite imagery. The field work visits were conducted weekly at different sites in the study area starting from beginning of March to the middle of April. More than 20 fields were sampled as a comprehensive sampling strategy. Within each field, four locations were chosen visually to collect samples to calculate PWC by averaging the four values and the mean was used. The coordinates of each was identified using a global positioning satellite (GPS). Samples were put in sealed plastic immediately after cutting and then taken to determine the fresh weight. To determine PWC, the whole plants were cut from an area of $1 \mathrm{~m}^{2}$ just above the ground level. The plant sample was weighed to determine fresh weight. Following oven drying at $70^{\circ} \mathrm{C}$ for 48 hours until a constant weight the dry weight was determined, and then PWC was calculated according to Mbow (1999) as follows:

$\mathrm{PWC}=\frac{F W-D W}{F W} * 100$

Where FW is the fresh weight of the sample in $\mathrm{g}$, DW is the oven dried weight of the same sample.

\section{RESULTS}

\section{Identifying different crops in the study area}

Mapping and monitoring agricultural crops at a regional scale using high resolution satellite imagery is crucial to avoid crop reductions by taking informed decisions that can help manage the limited water resources more efficiently. The ASTER image was used to map the concentration of PWC in wheat crops across the study area, south-west Nile Delta, Egypt. Care was taken to collect ground reference data from slightly larger fields to avoid the problem associated with mixed pixels from fields smaller than $15 \mathrm{~m}$ width. The field campaign attempted to collect data throughout the whole study area. In minimum distance supervised algorithm (MD), a validation dataset, which was independent from the training dataset, was created manually. The validation dataset composed at least 1000 pixels for each class. The MD classification successfully produced 4 different classes including wheat, clover, bare soil and water. 
The spectral signature from wheat fields is spectrally distinct from other classes. A confusion matrix was derived for MD of the $24^{\text {th }}$ March ASTER image to evaluate the classification results. Results of the confusion matrix (Table 1) showed high overall accuracy and high Kappa coefficient (94.5 and $89.9 \%$ respectively). Wheat crops occupy 53\% of the whole cultivated area. With regard to these results, very few fields are cultivated with barely $(<5 \%)$ particularly at the edge between desert and the cultivated land and these were misclassified as wheat.

Table 1 Confusion matrix results for MD algorithm of wheat and other crops in south-west Nile Delta, Egypt.

\begin{tabular}{l|cccccc}
\hline Class & \multicolumn{7}{|c}{ Ground truth (\%) } & User's \\
& Wheat & Clover & Bare & Water & Total & Accuracy \\
\hline Wheat & $\mathbf{9 7 . 1 4}$ & 26.98 & 7.55 & 2.11 & 7.99 & 81.60 \\
Clover & 0.00 & $\mathbf{7 3 . 0 2}$ & 0.14 & 0.00 & 1.15 & 95.83 \\
Bare soil & 2.86 & 0.00 & $\mathbf{9 2 . 3 1}$ & 1.69 & 33.62 & 96.69 \\
Water & 0.00 & 0.00 & 0.00 & $\mathbf{9 6 . 2 0}$ & 57.24 & 100.00 \\
Total & 100 & 100 & 100 & 100 & 100.00 & \\
\hline Producer's & 97.14 & 73.02 & 92.31 & 96.20 & & \\
\hline Overall Accuracy & $\mathbf{9 4 . 5}$ & \multicolumn{7}{|c}{} \\
\hline Kappa coefficient & $\mathbf{8 9 . 9}$ & & 7
\end{tabular}

Association between field measurements of PWC and vegetation indices

The derived vegetation indices, NDVI, RVI, GNDVI, and NDWI demonstrated the possibility of detecting PWC of wheat crops. The highest relationship was recorded between NDWI and PWC $\left(r^{2}=0.74\right)$. The second sensitive index was NDVI with a coefficient of determination of 0.71. RVI produced the lowest correlation with PWC $\left(\mathrm{r}^{2}=0.67\right)$. Generally, NDWI showed more sensitivity to PWC comparing with other tested indices. The region of SWIR centered at1656 $\mathrm{nm}$ wavelength showed higher sensitivity to the concentration of PWC. NDWI was calculated using $(1656,2167$, and 2209) of the SWIR region which produced respective $\mathrm{R}^{2}$ values of $0.74,0.43$, and 0.59 . These results show that $1656 \mathrm{~nm}$ wavelength is more sensitive to the amount of water in 
plants than the VNIR region. The regression analysis was also performed on the data collected during field survey to calculate regression equations for predicting PWC of wheat. Both NDWI and NDVI indices produced the strong correlations with PWC so they were used to calculate regression equations as follows:
$\mathrm{PWC}=1.25 \mathrm{NDWI}+0.98$
$\mathrm{R}^{2}=0.74, \mathrm{p}=0.00$
$\mathrm{PWC}=1.16 \mathrm{NDVI}-0.03$
$\mathrm{R}^{2}=0.71, \mathrm{p}=0.00$

As seen in Fig 2 a significant positive linear relationship between NDWI obtained from ASTER imagery and PWC $\left(\mathrm{R}^{2}=0.74 ; \mathrm{p}=0.000\right)$. A few outliers exist which may be due to changes in weather conditions.

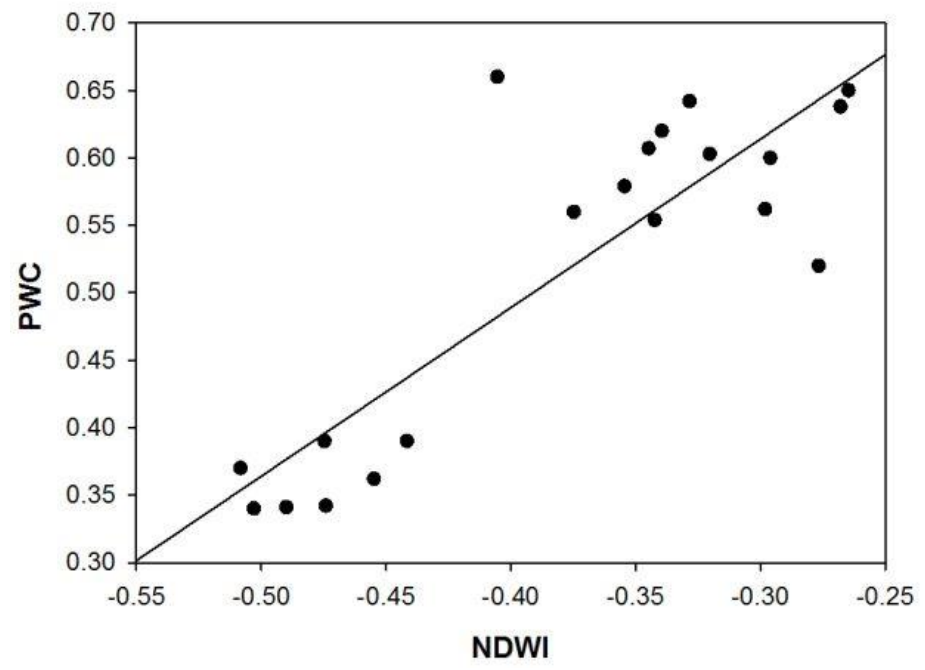

Fig.2 The relationship between NDWI and plant water content of wheat crops in south and west Nile Delta, Egypt $(n=20)$

\section{Mapping plant water content at a regional scale}

The classified ASTER image was then used to map PWC across the whole region. It was masked to wheat class only using image masking procedure in ENVI v4.7 and the band math was run to create NDVI and NDWI calibrated images for the whole scene to relate them to PWC. NDVI and NDWI maps were created to show variations in crop water status throughout the region. Both maps demonstrated that stress is noticeable at the border between Delta and desert region. PWC increases from the edge of the cultivated area to the middle of the Nile Delta where 
water is available over the growing season. This may have been a result of the dried edges of leaves as a result of water stress in these areas. Figures 3 and 4 show increases in NDVI and NDWI values gradually from the edge of the cultivated area in the west and south directions to the middle of the Nile Delta. This may have been a result of many factors. The most important is likely to be the unequal distribution of the water budget on the whole cultivated land in the Nile Delta since the irrigation canal network was established more than 100 years ago and lacks the distribution efficiency necessary for existing demands. The extreme weather conditions associated with the desert climate results in extreme evapotranspiration that when coupled with areas served by an efficient irrigation network can result in severe water stress, especially in some areas served by the end of the canal network.

Modern irrigation systems such as drip and sprinkler irrigation have a possible solution since it is more efficient in applying irrigation water to crops with high overall efficiency $(<80 \%)$. In modern irrigation systems, chemicals (fertilizers, fungicides and pesticides) can be added through and thus reducing the cost of labour.

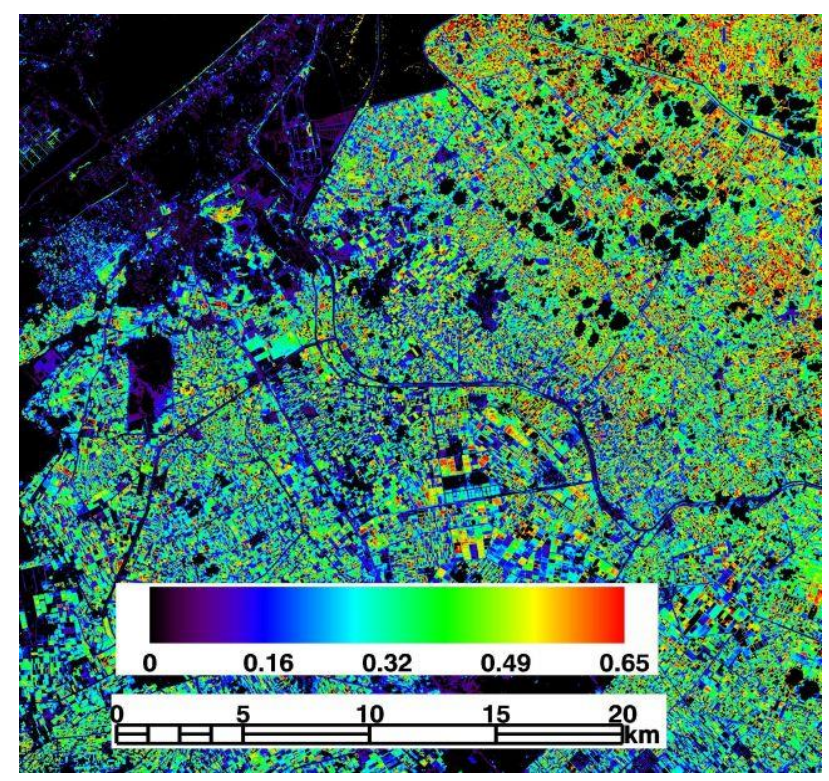

Fig. 3 classified ASTER NDVI image acquired on $24^{\text {th }}$ March calibrated to plant water content of wheat in south and west Nile Delta, Egypt. 


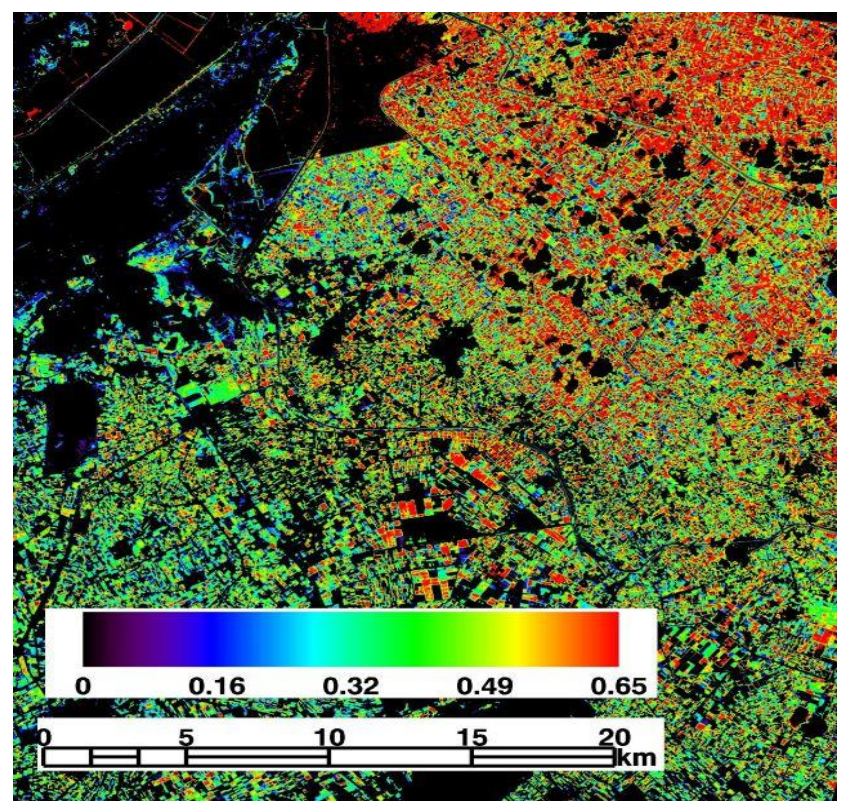

Fig. 4 classified ASTER NDWI image acquired on $24^{\text {th }}$ March calibrated to plant water content of wheat in south and west Nile Delta, Egypt.

\section{DISCUSSION AND CONCLUSION}

Vegetation indices derived from the $24^{\text {th }}$ March ASTER image was tested in this research for the detection of plant water content. NDVI, RVI, GNDVI $_{b r}$ and NDWI were considered as indicators of the amount of water in plants. The results demonstrated high sensitivity of vegetation indices based on VNIR and SWIR to plant water content of wheat crops across the study area. The strongest correlation was recorded between NDWI based on the region centred at $1656 \mathrm{~nm}$ and plant water content $\left(\mathrm{R}^{2}=0.74, \mathrm{p}=0.00\right)$ followed by NDVI $\left(\mathrm{R}^{2}=0.71, \mathrm{p}=0.00\right)$. The results further showed that NDWI based on wavelengths centred at 2167 and $2209 \mathrm{~nm}$ wavelengths produced weaker relationships with PWC comparing to the one at $1656 \mathrm{~nm}$.

The derived NDVI and NDWI maps have systematic spatial trends for crop water content. It was shown that at the border between the Nile Delta and desert the plant water content has low values in comparison with the crops at the centre of the Delta. These indices have been used in many previous studies for detecting crop water content (Jackson et al., 
2004; Cheng et al., 2013). Very few studies focused on the detection of plant water content of agricultural crops using high resolution imagery. Some of these studies based their work on the VNIR region only. In the 1980s and 1990s there were many challenges for using satellite images in monitoring crop water status particularly agricultural crops. This can be related to a few things including; the revisit period of the sensor, number of spectral bands in most satellite sensors.

The big challenge of using coarser resolution satellite imagery $(15 \mathrm{~m}$ to $30 \mathrm{~m}$ ) is the small field system in the Nile Delta. Although lacking spatial detection within and across small fields, the broad underlying trends can still be noticed over the region. Improvements in remote sensing capabilities in terms of spectral and spatial resolution seem to increase the efficiency of this technique to monitor crop water status. The forthcoming launch of the Sentinel 2 in 2014, as part of ESA's GMES programme may provide a possible platform for the detection of crop stress over small fields. The $10 \mathrm{~m}$ resolution in the VNIR combined with the $290 \mathrm{~km}$ swath and short revisit time provides changes in the ability to monitor crops throughout the growing season. The results presented suggest that using a combined set of high resolution $(2-5 \mathrm{~m})$ (e.g. QuickBird and GeoEye-1) and lower resolution (10-30) (e.g. Sentinel 2 and Landsat 8) satellite imagery will be very effective in monitoring plant water status at both within field and regional scales.

This study assess the potential of high spatial resolution remote sensing imagery to detect and map variations of plant water content in wheat crops in the Nile Delta region of Egypt. The results revealed significant relationships between field measurements of PWC and vegetation indices derived from ASTER imagery. Both NDWI and NDVI showed sensitivity to PWC. SWIR based index showed higher sensitivity to PWC than VNIR based indices (e.g. NDVI and RVI). The relationship was stronger at the $1656 \mathrm{~nm}$ wavelength which produced the highest value of coefficient of determination $\left(\mathrm{R}^{2}=0.74\right)$. The results of this research give a step forward for the early detection of crop water status using high resolution satellite imagery and thus can be a robust tool in precision irrigation management. The PWC maps at a large scale may help for 
monitoring irrigated districts more efficiently and therefore increase water productivity.

\section{REFERENCES}

Ben-Gal, A., N. Agam, V. Alchanatis, Y. Cohen, U. Yermiyahu, I. Zipori, E. Presnov, M. Sprintsin, and A. Dag. 2009. Evaluating water stress in irrigated olives: correlation of soil water status, tree water status, and thermal imagery. Irrigation science. 27: 367-376.

Ceccato, P., S. Flasse, and J. Gregoire. 2002. Designing a spectral index to estimate vegetation water content from remote sensing data: part 2. Validation and applications. Remote sensing of Environment. 82: 198-207.

Ceccato, P. S. Flasse, S. Tarantola, S. Jacquemond, and J. Gregoire. 2001. Detecting vegetation water content using reflectance in the optical domain. Remote sensing of Environment. 77: 22-33.

Chen, D., J. Huang, and T. J. Jackson. 2005. Vegetation water estimation for corn and soybeans using spectral indices derived from MODIS near- and short-wave infrared bands. Remote Sensing of Environment. 98: 225-236.

Cheng, T., D. Riano, A. Koltunov, M.L. Whiting, S.L. Ustin, and J. Rodrigues. 2013. Detecting of diurnal variation in orchard canopy water content using MODIS/ASTER airborne simulator (MASTER) data. Remote Sensing of Environment. 132: 1-12.

Cheng, Y. B., S. L. Ustin, D. Riano, and V. C. Vanderbilt. 2008. Water content estimation from hyperspectral images and MODIS indexes in Southeastern Arizona. Remote Sensing of Environment. 112: 363-374.

Fourty, T. and F. Baret. 1997. Vegetation water and dry matter contents estimated from top-of-the-atmosphere reflectance data: a simulation study. Remote Sensing of Environment. 6: 34-45.

Gao, B. 1996. NDWI-a normalized difference water index for remote sensing of vegetation liquid water from space. Remote Sensing of Environment. 58: 257-266. 
Jackson, T. J., D. Chen, M. Cosh, F. Li, M. Anderson, C. Walthall, P. Doriaswamy, and E. R. Hunt. 2004. Vegetation water content mapping using Landsat data derived normalized difference vegetation index for corn and soybeans. Remote Sensing of Environment. 9: 475-482.

Mbow, C. 1999. Proposition of a method for early fires planning using ground and satellite (NDVI/NOAA-AVHRR) data Niokolo Koba National Park (southeast Senegal). Poster Presentation in Proceeding of the second international Symposium on Operationalization of Remote Sensing, 16-20 August 1999, ITC, Enschede, the Netherlands.

Penuelas, J., I. Filella, R. Sav, and L. Serrno. 1996. Cell wall elasticity and water index (R970/R900) in wheat under different nitrogen availabilities. International Journal of Remote Sensing. 17: 373382.

Penuelas, J., J. Pinol, R. Ogaya and I. Filella. 1997. Estimation of plant water concentration by the reflectance water index WI (R900/R970). International Journal of Remote Sensing. 18(13): 2869-2875.

Ren, J., Z. Chen, Q. Zhou and H. Tang. 2008. Regional yield estimation for winter wheat with MODIS-NDVI data in Shandong, China. International Journal of Applied Earth Observation and Geoinformation. 10: 403-413.

Sun, H-Y., C-M. Liu, X-Y. Zang, Y-J. Shen and Y-Q. Zang. 2006. Effects of irrigation on water balance yield and WUE of winter wheat in the North China Plain. Agricultural Water Management. 85: 211-218.

Tucker, C.J., J. Pinzon, M.E. Brown, D.A. Slayback, E.W. Pak, R. Mahoney, E.F. Vermote and N. El Saleous. 2005. An extended AVHRR 8-km NDVI dataset compatible with MODIS and SPOT vegetation NDVI data. International Journal of Remote Sensing. 26: 4485-4498. 


\section{الملخص العربي}

\section{عمل خرائط للمحتوى المائى لمحصول القمح باستخدام صور الاقمار الصناعية}

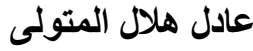

ان استخدام الاستشعار عن بعد فى متابعة وتقدير الحالة المائية للمحاصيل الزراعية ذو اهمية خصوصا فى المناطق التى تعانى شحة المياه كما فى مصر حيث أنه يعطى رؤية مبكرة عن النى

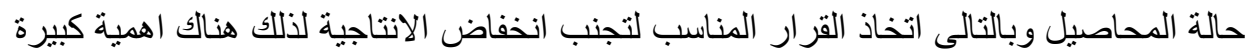

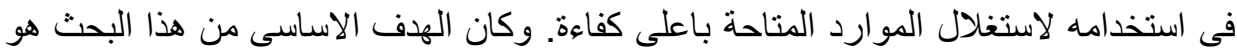

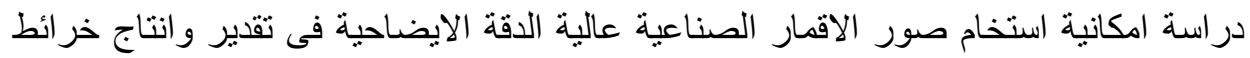
المحتوى المائى لمحصول القمح على نطاق كبير. ولقد تمت الزيارات الحقلية لهذا البحث

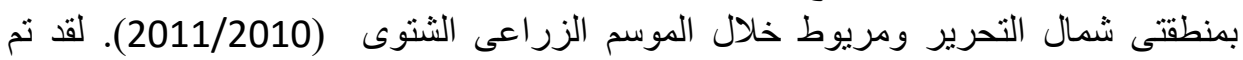

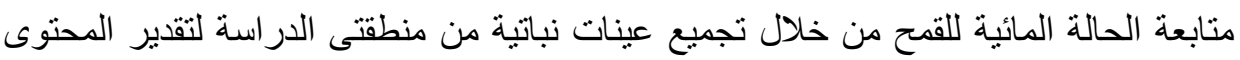

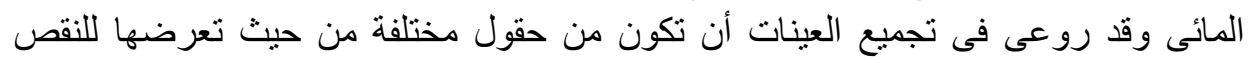

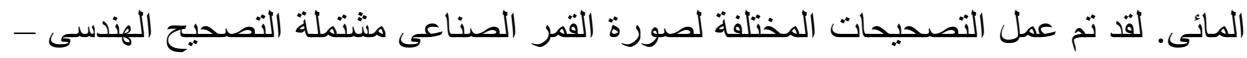
التصحيح التاتج من تأثنير الطقس - وكذلك عمل التصنيف وتم ذلك باستخدام برنامج (Envi). وبعد اشتقاق المؤشر ات الخضرية المختلفة من الصور المصححة تم دراسة علاقة الارتباط بين

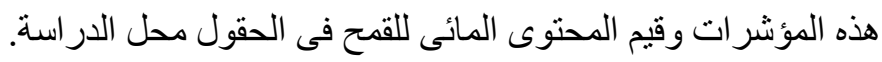
وكانت أهم النتائج مايلى أنى

تعتبر صور الاقمار الصناعية من نوع استر ذات فاعلية كبيرة فى اعطاء رؤية

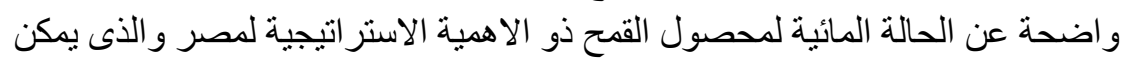

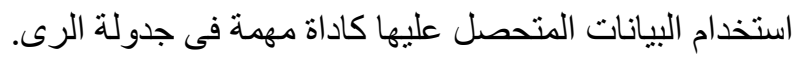
يعتبر المؤشر الخضري NDWI ذات حساسية كبيرة لحالة محصول القمح المائية

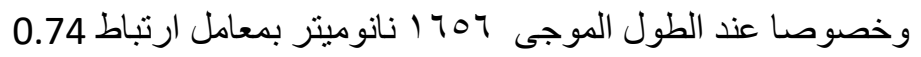
احتو اء صور استر على المنطفة SWIR يعطى حساسية أعلى للمحتوى المائى مقارنة بمناطق Red و RIR الموجودة في أنواع صور أقمار صناعية أخرى

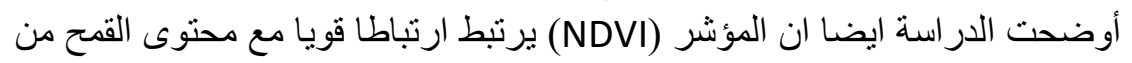
الماء حيث كانت قيمة معامل الارتباط 0.71.

يتضح من هذه الدراسة ان صور الاقمار الصناعية عالية الدقة يمكن ان تساعد بشكل كبير فى الثى ادارة الموارد المتاحة من مياه بشكل فعال يعمل على تجنب اسباب انخفاض انتاجية المحاصيل

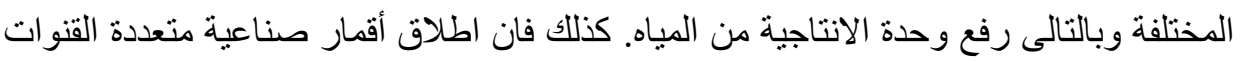

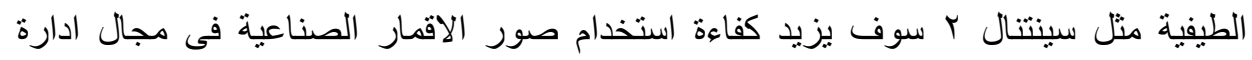

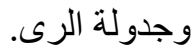

مدرس الهندسة الزراعية ـ قسم الهندسة الزراعية ـ كلية الزراعة ـ جامعة طنطا مصر 